\title{
A MISCELÂNEA DIGITAL PARA ALÉM DA DESORDEM
}

\author{
EIS MÁS ALLÁ DEL TRASTORNO DE VARIOS DIGITAL
}

WEINBERGER, David. A nova desordem digital: os novos princípios que estão reinventando os negócios, a educação, a política, a ciência e a cultura. Rio de Janeiro: Elsevier; Campus, 2007. 273 p.

Por que escolher uma única árvore quando podemos ter toda a floresta à nossa disposição?

Nesta questão lançada pelo autor, a árvore figura como uma estrutura simbólica de identidade com o esquema hierárquico de representação do conhecimento, e a floresta, como forma de representar as multipotencialidades rizomáticas do universo digital. Este é apenas um dos questionamentos metafóricos suscitados na obra de David Weinberger sobre a mixórdia da era digital e a relação dialética entre os esquemas de organização da informação empreendidos pela humanidade.

O estadunidense Weinberger é pesquisador atuante na área de marketing digital. Entre suas publicações existem obras consagradas, como The Clue Train Manifesto e Small Pieces Loosely Joined, ambas de forte repercussão entre os estudiosos dos fenômenos econômicos e sociais provocados pela Web.

Em "A nova desordem digital: os novos princípios que estão reinventando os negócios, a educação, a política, a ciência e a cultura" (2007), tradução do original em inglês de mesma data de primeira edição "Everything is miscellaneous: the power of the new digital disorder", o autor inicia o prólogo e se estende ao primeiro capítulo "A nova ordem da ordem", abordando as limitações e a simplicidade da organização das coisas no mundo físico, dos átomos, as quais não são extensíveis e apropriadas ao mundo digital, ou seja, dos bits.

A obra é dedicada aos bibliotecários e está estruturada em dez capítulos, que versam, basicamente, sobre o novo paradigma de organização do conhecimento.

Para Weinberger, a organização no espaço de bits transcende as organizações fixas, cartesianas e estanques, pois cede espaço à designação múltipla e à onipresença 
dos conteúdos em diferentes contextos. Tais argumentos sustentam as chamadas "três ordens da ordem" forjadas pelo autor.

$\mathrm{Na}$ concepção de Weinberger, as duas primeiras "ordens da ordem" estão condicionadas ao plano físico das coisas, porém o que as diferencia é que, enquanto a primeira organiza fisicamente, a "segunda ordem da ordem" exerce função complementar, ao preocupar-se com a elaboração de instrumentos que auxiliem na recuperação do plano físico organizado.

Dessa forma, a "primeira ordem da ordem" está relacionada ao agrupamento das coisas/objetos respeitando-se uma disposição física por características, associações e semelhanças predeterminadas, como livros que são dispostos sequencialmente em estantes por um esquema de agrupamento por assuntos e produtos que são alocados em prateleiras de supermercados. Por outro lado, a segunda ordem poderia ser representada pelos catálogos e índices utilizados em bibliotecas e pelas sinalizações que nos orientam em lojas e supermercados, fazendo referência à organização de primeira ordem.

A primeira e a segunda "ordens da ordem" seguem as seguintes premissas: 1) no mundo físico, algumas coisas estão mais próximas do que outras; 2) objetos físicos podem estar em um único lugar em um mesmo tempo; 3) o espaço físico é compartilhado, então há limitação de layout, embora possa haver diferentes necessidades; 4) as habilidades físicas humanas são limitadas e, 5) a organização da armazenagem deve ser ordenada e arrumada.

Diferentemente, na "terceira ordem da ordem" há uma ruptura com a ideia de que espaços físicos bem-organizados são transpostos para o universo digital. A destreza da humanidade para organizar e agrupar coisas é posta em xeque, uma vez que o caos e a miscelânea, para o autor, são virtudes que superam os esquemas segmentados e hierárquicos tradicionais, os quais se mostram falíveis para organizar o espaço de bits.

Nos capítulos que seguem - "Classificação em ordem alfabética e seus opositores", "A geografia do conhecimento" e "Divisões e separações" - Weinberger resgata diversos esquemas de representação e organização do conhecimento que continuam a influenciar o esquema societário e suas representações, passando pela filosofia aristotélica e a sua contribuição hierárquico-classificatória, que orientou e permanece a orientar, sobretudo, as representações ocidentais, e ainda pelos sistemas de classificação propostos por Panizzi, Jewett e Dewey, pelas leis e facetas de Ranganathan, pela ordenação enciclopédica, pela tabela periódica de Mendeleev, bem como pelo esquema taxonômico das espécies proposta pelo sueco Carolus Linnaeus e aprimorado posteriormente pelo naturalista francês Lamarck, entre outros. 
Paralelamente à exposição das teorias e técnicas que por séculos influenciam os modos de organizar o mundo, o autor ocupa-se em demonstrar que essas teorias são válidas exclusivamente para a organização de primeira e segunda ordem e a sua falibilidade na chamada "Lei da selva" (título do quinto capítulo), argumento que segue nos capítulos: "Folhas Inteligentes", "Conhecimento Social", "Palavras que nada dizem" e "A confusão como virtude" contando-se com ilustrações, exemplos e relações análogas a situações de nosso cotidiano.

Os espaços de controle de vocabulário por meio de tesauros, planos definidos de classificação e categorização que registram aderência social até os primórdios da World Wide Web, já não são suficientes e adequados para o contexto da Web 2.0. A visão tradicional do conhecimento organizado pelos ditos experts por meio de esquemas exatos, que tendem a minimizar ou erradicar ambiguidades e buscam planificar a realidade de forma única, é substituída por esquemas colaborativos de produção de informação, pela folksonomia e "etiquetagens" sociais e pelas formas customizadas de ordenação.

Esses aspectos direcionam a novas propriedades e estratégias e a um novo conhecimento dos quais emergem quatro princípios sinalizados na obra: 1) a filtragem inclusiva que, ao contrário da filtragem exclusiva, busca aumentar o potencial do conhecimento produzido e compartilhado socialmente; 2) a multiassociação de conteúdos, uma vez que cada informação (folha) pode e deve estar relacionada ao maior número de categorias (galhos) imagináveis; 3) a potência de tudo ser metadado, portanto, tudo poder ser etiquetado e, 4) a necessidade da desistência do controle sob a ordenação.

Por evocarem a ideia de desordem, o heterogêneo e a miscelânea incomodam; mas a dita desordem do espaço de bits dá-se por entrelaçamentos e misturas que, aos olhos de Weinberger, resultam na inesgotável fonte de conhecimento que é aberto e rompe as barreiras do definitivo, do sectário e do essencialismo. Para o autor, "[...] o significado de determinada coisa é proporcionado pela rede de significados implícitos pelos quais chamamos de mundo" (WEINBERGER, 2007, p.172). Todo fenômeno de significado surge da heterogeneidade.

Nessa linha de raciocínio, alguns recursos da denominada Web 2.0 que são tidos como verdadeiros fenômenos sociais, a exemplo dos blogs, da Wikipédia, do Delicious, dos mashups, das redes de relacionamento e de compartilhamento de fotos como o Flickr e o Picasa, são apresentados pelo autor como formas de manifestar a inversão da pirâmide de produção e domínio top-down do conhecimento produzido socialmente, para uma relação bottom-up. 
Como não poderia deixar de ser, a Web Semântica, as ontologias, a linguagem de marcação extensível XML e os esquemas de representação pelos Resource Descriptive Frameworks (RDFs) que visam potencializar as descrições de metadados em ambiente web, também são alvos de discussão na obra.

O autor assevera que para se trabalhar a confusão semântica é importante investir nos microformatos, nas etiquetas/tags/rótulos gerados em pequenos grupos, pois, em sua visão, "[...] uma web semântica mundial é tão ambiciosa que cai nos mesmos problemas que incomodavam Dewey e grandes taxonomias" (WEINBERGER, 2007, p.198). Os agrupamentos mais soltos e imperfeitos, em nível local, tornam-se mais verossímeis, pois mantêm os significados implícitos, de desafiante descrição.

Não há ordem definitiva e não é possível plotarmos de uma vez todas as relações implícitas em um novo domínio. A complexidade constitui-se como o melhor cenário, de acordo com Weinberger, porque finalmente nos conduz ao conhecimento que não é unidirecional.

Em seu capítulo final, "O trabalho do conhecimento", o autor enfatiza a necessidade de enxergar o significado da miscelânea para além da confusão, algo que a terceira ordem permite. Para ele, o sonho do racionalismo isento de ambiguidades e de suprimida heterogeneidade manifesta-se como um controle social sufocante, não condizente com a desterritorialização do conhecimento. As sedes são móveis e a complexidade do novo sistema de organização é ditada pelo próprio usuário-produtor.

Renata Gonçalves Curty recurty@gmail.com

Professora Departamento de Ciência da Informação

Universidade Estadual de Londrina

\section{Title}

The digital miscellaneous beyond the disorder

\section{Título}

Interdisciplinariedad y transversalidad en Ciencia de la Información 